\title{
Small shards and long distances - three cryptotephra layers from the Nahe palaeolake including the first discovery of Laacher See Tephra in Schleswig-Holstein (Germany)
}

\author{
SASCHA KRÜGER ${ }^{1,2 *}$ (1) and CHRISTEL VAN DEN BOGAARD ${ }^{3}$ \\ ${ }^{1}$ Centre for Baltic and Scandinavian Archaeology, Stiftung Schleswig-Holsteinische Landesmuseen, Schloss Gottorf, Schleswig, \\ Germany \\ ${ }^{2}$ Institute of Prehistoric and Protohistoric Archaeology, Christian-Albrechts University, Kiel, Germany \\ ${ }^{3}$ GEOMAR - Helmholtz Centre for Ocean Research, Kiel, Germany
}

Received 16 March 2020; Revised 30 October 2020; Accepted 15 November 2020

\begin{abstract}
Investigations of Lateglacial to Early Holocene lake sediments from the Nahe palaeolake (northern Germany) provided a high-resolution palynological record. To increase the temporal resolution of the record a targeted search for cryptotephra was carried out on the basis of pollen stratigraphy. Three cryptotephra horizons were detected and geochemically identified as G10ka series tephra (a Saksunarvatn Ash), Vedde Ash and Laacher See Tephra. Here we present the first geochemically confirmed finding of the ash from the Laacher See Eruption in Schleswig-Holstein-extending the so far detected fallout fan of the eruption further to the north-west. These finds enable direct stratigraphical correlations and underline the potential of the site for further investigations.

(C) 2020 The Authors. Journal of Quaternary Science Published by John Wiley \& Sons Ltd.
\end{abstract}

KEYWORDS: cryptotephra; Laacher See Tephra; Saksunarvatn Ash; Vedde Ash

\section{Introduction}

Schleswig-Holstein, the northernmost German federal state, holds a key position in palaeo-environmental as well as archaeological research of the Lateglacial and Early Holocene. This is due to the fact that the region provided a north-facing corridor after the retreat of the glaciers. Despite numerous palaeo-environmental investigations (Krüger et al. 2020 and literature cited therein), a correlation of the individual records is difficult because age modelling is mainly missing, or because of hiatuses (Usinger 1981). The analyses of sediment cores from the Nahe palaeolake (NAH; Dreibrodt et al. 2020; Krüger et al. 2020) fill a gap in Lateglacial/Early Holocene palaeo-environmental research in Schleswig-Holstein. For the first time a complete Lateglacial to Early Holocene sequence is described without being affected by the Allerød-Younger Dryas hiatus that had been documented for numerous lake sediments in northern Germany and Denmark (Krüger and Damrath 2019; Bennike et al. 2004; Usinger 1981). Furthermore, a sequence of the sediment is annually laminated, allowing for a high resolution of the temporal scale (Dreibrodt et al. 2020). Therefore, an attempt was made to identify tephra layers as additional chronological horizons to supplement radiocarbon dating of macrofossils, as volcanic ash layers mainly represent single events. This would, moreover, provide the opportunity to directly correlate the record with important European key sites of Lateglacial-Early Holocene research. However, while recording and describing the $\mathrm{NAH}$ sediment sequence, no visible ash horizons could be detected.

The advancements in search techniques for non-visible volcanic ash beds, or cryptotephra, have widened the possibilities of searching for additional chronological markers in sediment archives (Blockley et al. 2005; Lowe and Hunt 2001; Turney 1998;

*Correspondence: Sascha Krüger, as above.

E-mail: sascha.krueger@zbsa.eu
Turney et al. 2004). In this way the detection of non-visible tephra horizons has been extended to further distal sites throughout Europe (Blockley et al. 2007; Bramham-Law et al. 2013; Haflidason et al. 2018; Lane et al. 2012b; Larsson and Wastegård 2018; Wastegård and Boygle 2012; Wastegård et al. 2000; Wulf et al. 2013). Palaeo-environmental studies provide the possibility of combining specific tephra horizons with pollen stratigraphy. Conversely, this implies that pollen stratigraphy can be used to locate the position of non-visible ash beds in sediment sequences. To successively increase the temporal resolution of the NAH sediment record a targeted search for well-dated cryptotephra horizons was performed based on their expected position in pollen stratigraphy. We aimed at searching for cryptotephra of the Vedde Ash (VA) and Laacher See Tephra (LST). Apparently, the Saksunarvatn Ash (SA) is the product of a series of eruptions in the Grímsvötn system and hence, does not represent one fixed event date (Davies et al. 2012; Harning et al. 2018; Óladóttir et al. 2020). However, this study also attempts to identify the SA/G10ka series tephra at least as an event interval (Óladóttir et al. 2020).

The SA was erupted in the Grímsvötn volcanic system in the Eastern Volcanic Zone on Iceland. The ash has been described from numerous sites in Northern Europe from Iceland, the British Isles, Norway, the Faroe Islands, Greenland and the North Atlantic (Birks et al. 1996; Björck et al. 1992; Grönvold et al. 1995; Harning et al. 2018; Mangerud et al. 1984; Timms et al. 2017). In Germany, the ash has been recorded at Potremser Moor in Mecklenburg Western Pomerania (Bramham-Law et al. 2013) and in Schleswig-Holstein at two locations 30 and $50 \mathrm{~km}$ north-east of the Nahe palaeolake, Lake Plußsee and Lake Muggesfeld (Merkt et al. 1993). Furthermore, the visual evaluation of thin sections from Lake Belau revealed brownish cryptotephra shards that have been assigned to the G10ka series tephra on the basis of their morphology (pers. com. W. Dörfler). Most recently, Saksunarvatn 
tephra has also been discovered in a sediment sequence from Lake Poggensee (Zanon et al. 2019; Fig. 1).

The only known location at which the VA has been detected in Schleswig-Holstein is the site of Ahrenshöft. Here, the cryptotephra was found in two sediment profiles embedded in an archaeological context (Housley et al. 2012). Nevertheless, the tephra has not been found in the chronologically wellsecured context of a lake sediment sequence. As the Nahe palaeolake is situated within the known fallout zone of the VA, as suggested by Bramham-Law et al. (2013), Davies et al. (2012) and Wulf et al. (2016), this ash was suspected to be preserved in sediments from there.

The most prominent Lateglacial volcanic eruption in central Europe was the eruption of the Laacher See Volcano in western Germany. Dated to $12880 \pm 40$ varve a BP (Brauer et al. 1999), ash was distributed over wide areas of central Europe. Laacher See Tephra has been documented at more than 400 sites, extending from the Alps and central France to Bornholm and Poland (Bronk Ramsey et al. 2015; Riede 2016; Riede et al. 2011; Turney et al. 2006; van den Bogaard and Schmincke 1984). The LST, however, has so far not been identified in SchleswigHolstein, which is outside the known and documented visible fallout lobes.

The aims of this study were:

1. to detect cryptotephra horizons in NAH sediment cores based on their expected occurrence in pollen stratigraphy;

2. to geochemically fingerprint the tephra layers;

3. to gain additional chronological tie-points for the age-depth model of the $\mathrm{NAH}$ record;

4. to underline the potential of future research into NAH sediments regarding cryptotephra layer identification.

\section{Study site}

The NAH is located in Schleswig-Holstein about $30 \mathrm{~km}$ north of Hamburg (Germany). The basin of the former lake was part of a larger glacial lake system and is separated from further elongated incised lakes by two narrow sand ridges to the north-west and south-east (Smed 1998; Woldstedt 1935, 1954). To the south-east, Lake Itzstedt is the water-bearing remnant of the lake system.
The size of the palaeolake surface was about 16 ha during the Lateglacial (Fig. 1). The terrestrialisation process was completed in the course of the late Holocene. Today, the river Rönne flows in the centre of the still existing depression and thereby follows the course of the former lake in a northwesterly direction before turning southwards and draining off into the river Alster. The area is today used as pasture and partly forested by alder, birch and willow. The coring location is situated in the formerly deepest part of the incised lake $\left(53^{\circ} 48.711^{\prime} \mathrm{N}, 10^{\circ} 8.082^{\prime} \mathrm{E}\right)$.

At the coring location approximately $1.6 \mathrm{~m}$ of fen peat overlie a sequence of $12.2 \mathrm{~m}$ of predominantly detrital gyttja. The shift from the Lateglacial to Holocene is reflected in a gradual shift from clayish to calcareous and finally detrital gyttja. Lateglacial mainly organic depositions of $1.6 \mathrm{~m}$ thickness contain a $50 \mathrm{~cm}$ sequence of very fine annual lamination (Dreibrodt et al. 2020; Krüger et al. 2020). The sediment cores reached glacial sand at $15.8 \mathrm{~m}$. The chronology is based on AMS radiocarbon dates, pollen events, varve counting and additionally on the identified tephra layers (Dreibrodt et al. 2020).

\section{Methods}

\section{Field methods and sampling}

The coring campaign in the dry centre of the Nahe palaeolake took place in October 2017. A modified Livingston piston corer (Mingram et al. 2007)—the so called Usinger-corerwas used to extract the sediment cores. Two overlapping sediment sequences with a diameter of $80 \mathrm{~mm}$ and $16 \mathrm{~m}$ in length have been reached by coring. Each $1 \mathrm{~m}$ segment was cut longitudinally and stored as well as processed at the Institute for Pre- and Protohistoric Archaeology in Kiel, Germany. In order to connect the core sequences, a series of distinct layers and stratigraphic marker horizons have been defined in the parallel cores. In this way, a composite core was constructed, providing a continuous record avoiding gaps (Dörfler et al. 2012).

The interdisciplinary approach of the study requires that the results of different methods must be easily correlated across depths. Therefore, a grid of $5 \mathrm{~mm}$ step size was created spanning the lower $5 \mathrm{~m}$ of the sequence. Each sample was

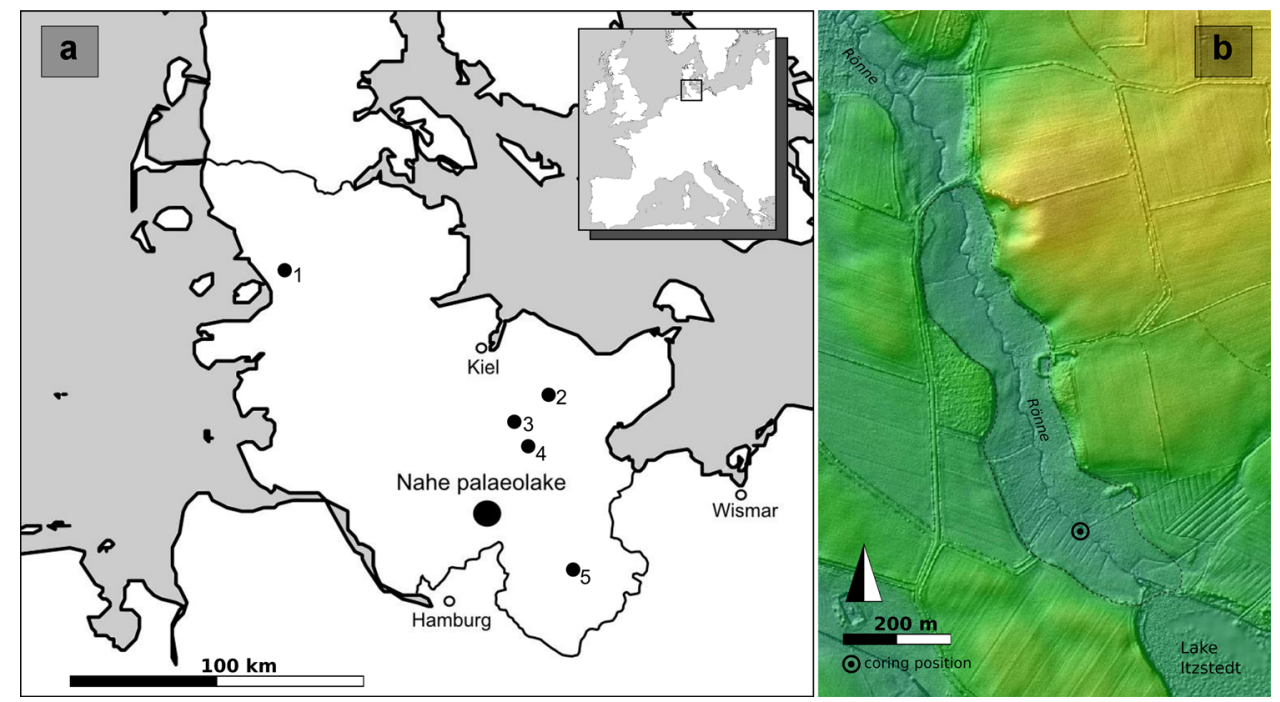

Figure 1. Location of the Nahe palaeolake (a) and coring location (b). DEM based on LVermGeoSH. 1-5 show sites as mentioned in the text. 1 - Ahrenshöft; 2 - Lake Plußsee; 3 - Lake Belau; 4 - Lake Muggesfeld; 5 - Lake Poggensee. [Color figure can be viewed at wileyonlinelibrary.com] 
labelled according to consecutive numbers (953 potential samples in total, $11.10-15.86 \mathrm{~m}$ below the surface).

\section{Pollen analysis}

Samples for pollen preparation were mostly taken every centimetre but at least every fourth centimetre. Sample preparation was carried out according to standard techniques (Erdtman 1960; Fægri and Iversen 1989). Lycopodium spore tablets were added to enable the calculation of pollen concentrations (Stockmarr 1971). Pollen counting was performed at a total magnification of $\times 400$ for routine counting and $\times 1000$ for critical objects. A pollen sum of at least 550 TTP (total terrestrial pollen) per sample was achieved. Pollen identification followed mainly Beug (2004) as well as Moore et al. (1991). The reference collection at the Institute of Preand Protohistoric Archaeology in Kiel was further consulted. The results were visualised using the CountPol software (I. Feeser, Kiel University) as well as Inkscape (ver. 0.92.4). The general results of the pollen analysis of the complete section are presented by Krüger et al. (2020).

\section{Tephra analysis and identification}

On the basis of the preceding pollen analysis and a preliminary comparison of these results with investigations in northern central Europe (Krüger et al., 2020), certain sequences were selected for a search for cryptotephra (Fig. 2). The selected depths were sampled in $2 \mathrm{~cm}$ steps (Lateglacial sequence) and $1 \mathrm{~cm}$ steps (Holocene sequence) resulting in sample weights between 5 and $11 \mathrm{~g}$. The chemical preparation included treatment with $\mathrm{HCl}$ to dissolve carbonates, concentrated $\mathrm{H}_{2} \mathrm{SO}_{4}$ and $\mathrm{HNO}_{3}$ to remove the organic material from the samples and $\mathrm{KOH}(10 \%)$ to eliminate diatom silicates. Moreover, a density separation using sodium polytungstate was applied to separate heavy mineral particles of more than $2.7 \mathrm{~g} / \mathrm{cm}^{3}$ from the lighter particles (Turney 1998). The lighter fraction was mounted in glycerol-gelatine and subsequently analysed using a light microscope under bright field, $\times 250$ magnification. Cross-polarisation was additionally used to check critical particles. The identified cryptotephra horizons were labelled according to sample numbers. As one cryptotephra sample spans $2 \mathrm{~cm}$ (equalling four samples on the composite core) the bottom sample numbers according to the composite core were utilised for the tephra samples.

To gain material for electron-microprobe analyses (EMPA) the mounted material was re-dissolved and embedded in synthetic resin. Subsequently polished thin sections were prepared from these slides.

\section{Electron-microprobe analyses}

The major- and minor-element geochemistry of the glass shards was determined with the JEOL JXA 8200 electron microprobe equipped with five wavelength dispersive spectrometers at GEOMAR (Kiel, Germany). The analytical conditions were $15 \mathrm{kV}$ accelerating voltage, $6 \mathrm{nA}$ current and $5 \mathrm{\mu m}$ electron beam size. For calibration, a set of natural reference materials from the Smithsonian collection was used, the quality of the calibration was tracked by running the Lipari

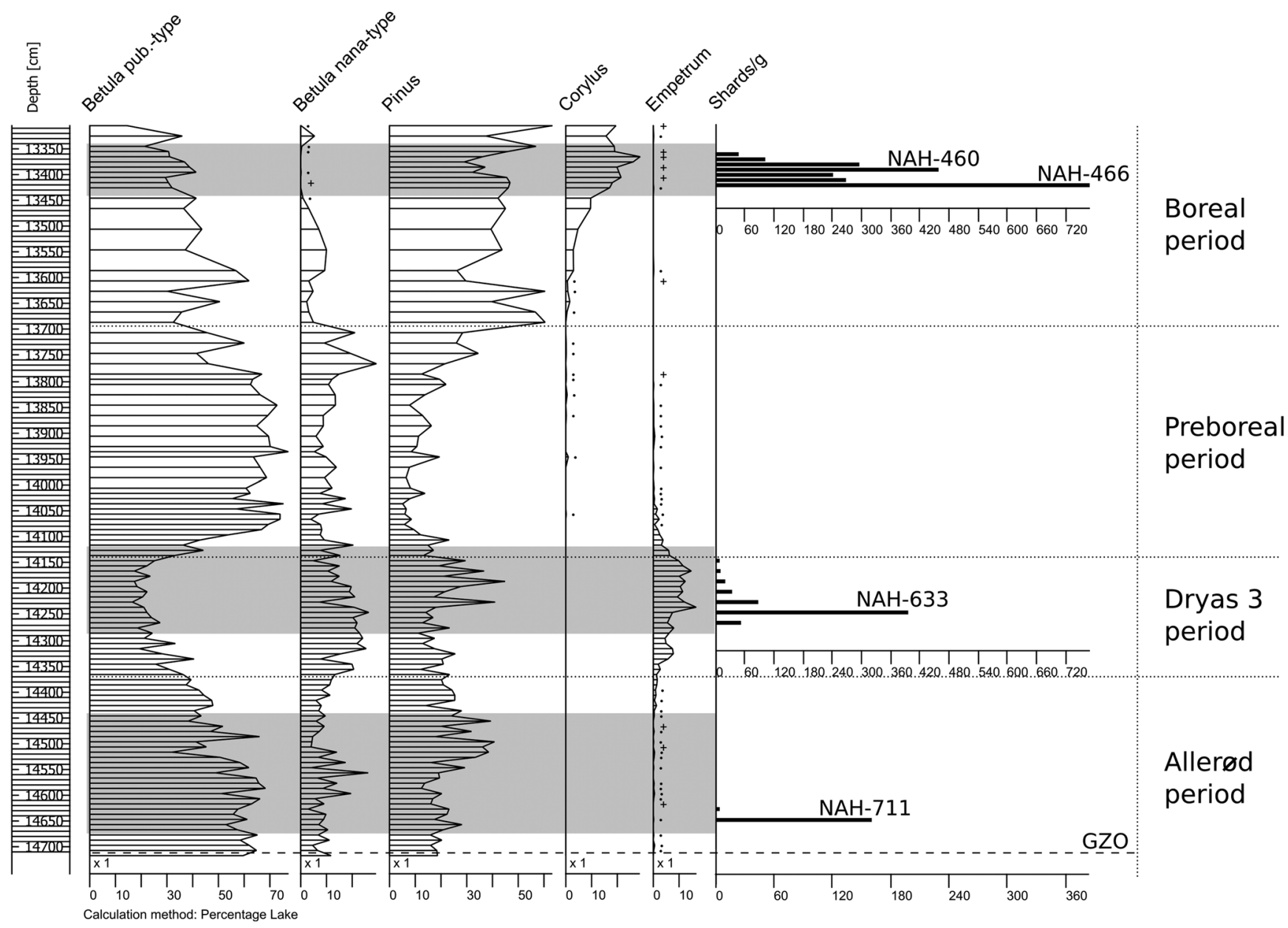

Figure 2. Overview of results of the targeted search. Sequences prepared for cryptotephra search are shaded in grey. The dashed line (labelled $\mathrm{GZO}$ ) indicates the local palynologically identified end of the Gerzensee Oscillation. 
obsidian standard as a secondary glass standard. The laboratory was part of the INTAV (International Quaternary Association's focus group on tephrochronology) comparison of tephrochronology laboratories, which confirmed the high quality of the major-element data produced by the instrument set-up (Kuehn et al. 2011). For further details on the analytical procedure see Dörfler et al. (2012) and Zanon et al. (2019). Analyses with totals $<95 \%$ were discarded. All data are plotted normalised to $100 \%$ volatile free. Average analyses are shown in Tables 1-3.

\section{Results and discussion}

A total of 39 sediment samples have been subject to the search for cryptotephra. The targeted search resulted in three clear cryptotephra shard concentrations of more than 350 shards/g (or 150 shards/g at generally lower concentrations). The outcome of the targeted search is displayed in Fig. 2. Shard sizes differ between 15 and $75 \mu \mathrm{m}$ (Fig. 3). Samples with peak shard concentrations were analysed for the geochemical composition of the shard population with EMPA.

\section{Identification, characterisation and correlation of tephra layers}

\section{$\mathrm{NAH}-466$}

The Saksunarvatn eruption(s) can be assigned to the phase of rapidly increasing Corylus (Hazel) pollen values during the Boreal period in northern central Europe (Bramham-Law et al. 2013; Merkt et al. 1993). As this increase is strikingly and unequivocally reflected in the $\mathrm{NAH}$ record (Krüger et al. 2020), a rough determination of the position of the ash could easily be made.

Here, the targeted search for cryptotephra revealed a twopart maximum of shards (Fig. 2) in samples NAH-460 (13.390-13.400 m) as well as NAH-466 (13.420-13.430 m). Both peaks (NAH-460 and 466) correlate to the rapid increase and first Corylus pollen maximum of the (biostratigraphical) Boreal period.
Shard counts of sample NAH-460 yielded about 450 shards/g and NAH-466 about 770 shards/g. The shards in both peak occurrences are exclusively brown in colour (Fig. 3a-b). The morphology of the glass shards is blocky, angular with curved shards, similar to that described by Merkt et al. (1993). The size spectrum ranges from 15 to $40 \mu \mathrm{m}$. Single shards with more than $60 \mu \mathrm{m}$ appeared rarely. Shards from sample NAH-466 were analysed for geochemical composition.

The glass shard population in the tephra horizon NAH-466 is geochemically homogeneous. The glass shards reveal a basaltic composition, with $49.6 \pm 0.3 \mathrm{wt} \% \mathrm{SiO}_{2}, 3.1 \pm 0.1 \mathrm{wt}$ $\% \mathrm{TiO}_{2}, 14.5 \pm 0.3 \mathrm{wt} \% \mathrm{FeO}, 10.1 \pm 0.2 \mathrm{wt} \% \mathrm{CaO}$ (Fig. 4). The full geochemical analyses are given in Table 1.

The chemical composition is consistent with the SA that erupted from the Grímsvötn volcanic system on Iceland (Andrews et al. 2002; Bramham-Law et al. 2013). Tephra of this age, brownish glass shards and the same major- and minor-element composition, has been described at several terrestrial sites in Northern Europe, in marine cores in the North Atlantic and also in the GRIP ice core (Fig. 5a).

However, a recent review by Óladóttir et al. (2020) emphasised that the SA at different locations derives from various eruptive pulses of the Grímsvötn volcanic system. Tephras associated with the SA G10ka tephra series are of a very similar chemical composition (Fig. 5b-e).

Due to the size of the glass shards in the NAH tephra and the still-missing interlaboratory comparison tests for calibrating the analytical machines, we abstained from analysing traceelement compositions.

The recently published data on Saksunarvatn-type tephra from Havnardalsmyren on the Faroe Islands revealed up to five tephras from the Grímsvötn volcanic system, deposited within an interval of about 400 years. Major-element geochemistry shows that two older cryptotephras (Havn 3 and 4) can be separated by lower $\mathrm{MgO}$ than $\mathrm{CaO}$ content from a visible Saksunarvatn tephra and two younger ashes (Wastegård et al. 2018). The glass shards from NAH-466 fall into the field of high Mg-Saksunarvatn tephra (Fig. 5).

The targeted search for SA revealed two separate peaks in shard concentrations that correlate to the phase of rapidly

Table 1. Geochemical data on glass shards from NAH-466 determined by electron-microprobe analysis.

\begin{tabular}{|c|c|c|c|c|c|c|c|c|c|c|c|c|c|c|c|}
\hline $\begin{array}{l}\text { *Volatile-free } \\
\text { normalised } \\
\text { values }\end{array}$ & $\mathrm{SiO}_{2^{*}}$ & $\mathrm{TiO}_{2^{*}}$ & $\mathrm{Al}_{2} \mathrm{O}_{3^{*}}$ & $\mathrm{FeO}_{\mathrm{tot}^{*}}$ & $\mathrm{MnO}^{*}$ & $\mathrm{MgO}^{*}$ & $\mathrm{CaO}^{*}$ & $\mathrm{Na}_{2} \mathrm{O}^{*}$ & $\mathrm{~K}_{2} \mathrm{O}^{*}$ & $\mathrm{P}_{2} \mathrm{O}_{5^{*}}$ & $\mathrm{~F}$ & $\mathrm{SO}_{3}$ & $\mathrm{Cl}$ & $\begin{array}{c}\text { Analysed } \\
\text { total }\end{array}$ & Comment \\
\hline NAH-466 & 49.66 & 3.17 & 13.06 & 14.57 & 0.19 & 5.65 & 10.21 & 2.66 & 0.48 & 0.35 & 0.11 & 0.23 & 0.03 & 97.47 & Saksunarvatn \\
\hline \multirow[t]{17}{*}{$>97 \%$} & 49.29 & 3.12 & 13.18 & 14.94 & 0.25 & 5.65 & 9.94 & 2.78 & 0.47 & 0.37 & 0.00 & 0.26 & 0.04 & 97.67 & Saksunarvatn \\
\hline & 48.97 & 2.69 & 13.52 & 14.27 & 0.22 & 6.25 & 10.71 & 2.66 & 0.39 & 0.32 & 0.10 & 0.15 & 0.04 & 98.42 & Saksunarvatn \\
\hline & 49.88 & 2.89 & 13.10 & 14.30 & 0.26 & 5.81 & 10.26 & 2.78 & 0.41 & 0.32 & 0.00 & 0.26 & 0.04 & 98.97 & Saksunarvatn \\
\hline & 49.80 & 3.15 & 13.08 & 14.82 & 0.23 & 5.38 & 9.99 & 2.78 & 0.46 & 0.30 & 0.03 & 0.15 & 0.03 & 99.40 & Saksunarvatn \\
\hline & 49.44 & 3.11 & 13.10 & 14.80 & 0.25 & 5.50 & 10.16 & 2.88 & 0.46 & 0.29 & 0.09 & 0.18 & 0.03 & 98.23 & Saksunarvatn \\
\hline & 49.45 & 3.00 & 13.10 & 14.42 & 0.23 & 5.93 & 10.12 & 2.95 & 0.46 & 0.35 & 0.00 & 0.25 & 0.06 & 97.63 & Saksunarvatn \\
\hline & 49.75 & 3.11 & 12.97 & 14.68 & 0.24 & 5.65 & 10.02 & 2.78 & 0.45 & 0.35 & 0.00 & 0.31 & 0.04 & 99.61 & Saksunarvatn \\
\hline & 50.01 & 3.20 & 13.10 & 14.28 & 0.25 & 5.54 & 10.14 & 2.70 & 0.49 & 0.30 & 0.00 & 0.19 & 0.03 & 97.40 & Saksunarvatn \\
\hline & 49.84 & 3.14 & 13.23 & 14.68 & 0.23 & 5.30 & 9.87 & 2.93 & 0.46 & 0.31 & 0.14 & 0.20 & 0.04 & 99.29 & Saksunarvatn \\
\hline & 49.71 & 3.14 & 13.13 & 14.60 & 0.27 & 5.56 & 10.07 & 2.76 & 0.46 & 0.30 & 0.05 & 0.23 & 0.04 & 98.60 & Saksunarvatn \\
\hline & 49.86 & 3.23 & 12.97 & 14.37 & 0.28 & 5.50 & 10.01 & 2.96 & 0.48 & 0.34 & 0.03 & 0.21 & 0.04 & 97.90 & Saksunarvatn \\
\hline & 49.40 & 2.90 & 13.54 & 14.24 & 0.22 & 5.89 & 10.30 & 2.78 & 0.44 & 0.27 & 0.05 & 0.24 & 0.05 & 97.29 & Saksunarvatn \\
\hline & 49.65 & 3.24 & 13.21 & 14.28 & 0.29 & 5.41 & 10.24 & 2.88 & 0.47 & 0.33 & 0.00 & 0.22 & 0.04 & 97.62 & Saksunarvatn \\
\hline & 49.76 & 3.16 & 13.06 & 14.70 & 0.18 & 5.49 & 9.98 & 2.91 & 0.49 & 0.27 & 0.06 & 0.23 & 0.04 & 97.68 & Saksunarvatn \\
\hline & 49.79 & 3.20 & 12.93 & 14.67 & 0.22 & 5.64 & 10.02 & 2.76 & 0.47 & 0.31 & 0.06 & 0.23 & 0.04 & 97.35 & Saksunarvatn \\
\hline & 49.29 & 3.17 & 13.04 & 14.86 & 0.21 & 5.60 & 9.95 & 3.07 & 0.47 & 0.34 & 0.00 & 0.21 & 0.04 & 98.01 & Saksunarvatn \\
\hline & 50.09 & 2.92 & 13.20 & 13.84 & 0.22 & 6.02 & 10.49 & 2.53 & 0.40 & 0.29 & 0.08 & 0.17 & 0.04 & 97.98 & Saksunarvatn \\
\hline avg. & 49.65 & 3.09 & 13.14 & 14.52 & 0.24 & 5.65 & 10.14 & 2.81 & 0.46 & 0.32 & 0.04 & 0.22 & 0.04 & 97.94 & \\
\hline $\pm 1 \mathrm{~s}$ & 0.29 & 0.15 & 0.17 & 0.29 & 0.03 & 0.24 & 0.21 & 0.13 & 0.03 & 0.03 & 0.04 & 0.04 & 0.01 & 0.75 & \\
\hline
\end{tabular}


Table 2. Geochemical data on glass shards from NAH-633 determined by electron-microprobe analysis.

\begin{tabular}{|c|c|c|c|c|c|c|c|c|c|c|c|c|c|c|c|}
\hline $\begin{array}{l}\text { *Volatile-free } \\
\text { normalised values }\end{array}$ & $\mathrm{SiO}_{2 *}$ & $\mathrm{TiO}_{2 *}$ & $\mathrm{Al}_{2} \mathrm{O}_{3^{*}}$ & $\mathrm{FeO}_{\text {tot }^{*}}$ & $\mathrm{MnO}^{*}$ & $\mathrm{MgO}^{*}$ & $\mathrm{CaO}^{*}$ & $\mathrm{Na}_{2} \mathrm{O}^{*}$ & $\mathrm{~K}_{2} \mathrm{O}^{*}$ & $\mathrm{P}_{2} \mathrm{O}_{5^{*}}$ & $\mathrm{~F}$ & $\mathrm{SO}_{3}$ & $\mathrm{Cl}$ & $\begin{array}{l}\text { Analysed } \\
\text { total }\end{array}$ & Comment \\
\hline NAH-633 & 71.24 & 0.27 & 14.04 & 4.01 & 0.18 & 0.18 & 1.45 & 4.94 & 3.66 & 0.03 & 0.13 & 0.03 & 0.17 & 96.83 & Vedde Ash \\
\hline \multirow[t]{14}{*}{$>95 \%$} & 70.60 & 0.34 & 13.98 & 4.31 & 0.10 & 0.50 & 2.01 & 4.82 & 3.30 & 0.05 & 0.15 & 0.02 & 0.17 & 98.09 & Vedde Ash \\
\hline & 71.77 & 0.28 & 13.73 & 4.00 & 0.16 & 0.17 & 1.42 & 4.76 & 3.66 & 0.04 & 0.11 & 0.02 & 0.17 & 97.51 & Vedde Ash \\
\hline & 71.30 & 0.33 & 13.60 & 4.19 & 0.13 & 0.22 & 1.41 & 5.21 & 3.55 & 0.06 & 0.33 & 0.03 & 0.17 & 99.42 & Vedde Ash \\
\hline & 71.64 & 0.31 & 13.89 & 3.82 & 0.13 & 0.27 & 1.41 & 4.95 & 3.55 & 0.03 & 0.27 & 0.04 & 0.18 & 98.28 & Vedde Ash \\
\hline & 71.35 & 0.29 & 13.77 & 3.97 & 0.09 & 0.26 & 1.38 & 5.36 & 3.50 & 0.05 & 0.16 & 0.00 & 0.18 & 95.00 & Vedde Ash \\
\hline & 71.59 & 0.30 & 13.66 & 3.83 & 0.14 & 0.17 & 1.44 & 5.27 & 3.56 & 0.03 & 0.08 & 0.03 & 0.19 & 96.84 & Vedde Ash \\
\hline & 71.43 & 0.28 & 13.88 & 3.78 & 0.17 & 0.19 & 1.39 & 5.25 & 3.61 & 0.03 & 0.30 & 0.02 & 0.18 & 97.42 & Vedde Ash \\
\hline & 71.28 & 0.30 & 13.98 & 3.88 & 0.18 & 0.22 & 1.42 & 5.14 & 3.56 & 0.04 & 0.16 & 0.02 & 0.17 & 97.17 & Vedde Ash \\
\hline & 71.61 & 0.32 & 13.74 & 3.79 & 0.14 & 0.23 & 1.45 & 5.21 & 3.51 & 0.01 & 0.23 & 0.02 & 0.18 & 97.63 & Vedde Ash \\
\hline & 71.02 & 0.30 & 14.15 & 3.93 & 0.19 & 0.19 & 1.46 & 5.17 & 3.51 & 0.08 & 0.10 & 0.04 & 0.17 & 95.01 & Vedde Ash \\
\hline & 71.59 & 0.32 & 13.62 & 3.73 & 0.13 & 0.20 & 1.48 & 5.35 & 3.52 & 0.05 & 0.22 & 0.02 & 0.18 & 94.97 & Vedde Ash \\
\hline & 71.13 & 0.31 & 13.54 & 3.95 & 0.15 & 0.23 & 1.49 & 5.54 & 3.64 & 0.02 & 0.14 & 0.04 & 0.18 & 95.68 & Vedde Ash \\
\hline & 71.11 & 0.30 & 13.79 & 3.97 & 0.17 & 0.20 & 1.40 & 5.45 & 3.61 & 0.00 & 0.17 & 0.04 & 0.18 & 95.95 & Vedde Ash \\
\hline & 71.08 & 0.27 & 13.99 & 3.76 & 0.19 & 0.17 & 1.53 & 5.32 & 3.64 & 0.06 & 0.20 & 0.09 & 0.19 & 94.88 & Vedde Ash \\
\hline avg. & 71.30 & 0.30 & 13.79 & 3.93 & 0.15 & 0.20 & 1.42 & 5.21 & 3.56 & 0.04 & 0.16 & 0.03 & 0.18 & 97.12 & \\
\hline $\pm 1 \mathrm{~s}$ & 0.29 & 0.02 & 0.18 & 0.15 & 0.03 & 0.08 & 0.15 & 0.22 & 0.09 & 0.02 & 0.08 & 0.02 & 0.01 & 1.33 & \\
\hline
\end{tabular}

increasing values of Corylus pollen in the $\mathrm{NAH}$ record. A $9 \mathrm{~cm}$ sediment sequence was sampled in $1 \mathrm{~cm}$ steps, equivalent to a rather narrow scope of investigation. As large-scale turbations have been excluded for the whole $\mathrm{NAH}$ sequence this result either reflects: (i) potentially two very closely spaced eruptions; or (ii) small-scale rearrangement, bioturbation or secondary inwash of shards.

(i) At Potremser Moor-an in-filled lake about $230 \mathrm{~km}$ east of NAH_Bramham-Law et al. (2013) recorded two close and significant peaks in tephra shard concentration that correlate to

Table 3. Geochemical data on glass shards from NAH-711 determined by electron-microprobe analysis.

\begin{tabular}{|c|c|c|c|c|c|c|c|c|c|c|c|c|c|c|c|}
\hline $\begin{array}{l}\text { *Volatile-free } \\
\text { normalised values }\end{array}$ & $\mathrm{SiO}_{2^{*}}$ & $\mathrm{TiO}_{2^{*}}$ & $\mathrm{Al}_{2} \mathrm{O}_{3^{*}}$ & $\mathrm{FeO}_{\mathrm{tot}^{*}}$ & $\mathrm{MnO}^{*}$ & $\mathrm{MgO}^{*}$ & $\mathrm{CaO}^{*}$ & $\mathrm{Na}_{2} \mathrm{O}^{*}$ & $\mathrm{~K}_{2} \mathrm{O}^{*}$ & $\mathrm{P}_{2} \mathrm{O}_{5^{*}}$ & $\mathrm{~F}$ & $\mathrm{SO}_{3}$ & $\mathrm{Cl}$ & $\begin{array}{c}\text { Analysed } \\
\text { total }\end{array}$ & Comment \\
\hline NAH-711 & 59.78 & 0.53 & 20.50 & 2.40 & 0.15 & 0.26 & 1.78 & 7.10 & 7.41 & 0.08 & 0.17 & 0.10 & 0.31 & 97.07 & LST \\
\hline \multirow[t]{30}{*}{$>96 \%$} & 60.61 & 0.49 & 20.72 & 1.90 & 0.05 & 0.20 & 2.31 & 6.29 & 7.35 & 0.08 & 0.08 & 0.06 & 0.26 & 97.85 & LST \\
\hline & 60.94 & 0.52 & 20.43 & 2.12 & 0.16 & 0.19 & 1.94 & 6.17 & 7.49 & 0.03 & 0.10 & 0.06 & 0.34 & 96.53 & LST \\
\hline & 59.90 & 0.53 & 20.52 & 2.26 & 0.16 & 0.28 & 1.61 & 7.21 & 7.45 & 0.07 & 0.15 & 0.11 & 0.33 & 96.83 & LST \\
\hline & 59.74 & 0.54 & 20.50 & 2.27 & 0.13 & 0.27 & 1.79 & 7.22 & 7.52 & 0.02 & 0.11 & 0.08 & 0.32 & 97.57 & LST \\
\hline & 59.83 & 0.51 & 20.46 & 2.32 & 0.19 & 0.28 & 1.74 & 7.27 & 7.33 & 0.06 & 0.11 & 0.07 & 0.31 & 97.15 & LST \\
\hline & 59.99 & 0.47 & 20.63 & 2.29 & 0.14 & 0.24 & 1.64 & 7.07 & 7.47 & 0.06 & 0.17 & 0.15 & 0.29 & 98.09 & LST \\
\hline & 59.98 & 0.53 & 20.59 & 2.31 & 0.10 & 0.22 & 1.64 & 7.02 & 7.55 & 0.05 & 0.19 & 0.07 & 0.35 & 97.12 & LST \\
\hline & 60.08 & 0.57 & 20.12 & 2.53 & 0.23 & 0.26 & 1.70 & 7.12 & 7.37 & 0.02 & 0.02 & 0.09 & 0.34 & 98.40 & LST \\
\hline & 60.06 & 0.49 & 21.18 & 2.13 & 0.15 & 0.23 & 2.57 & 6.58 & 6.61 & 0.00 & 0.14 & 0.09 & 0.23 & 97.30 & LST \\
\hline & 59.66 & 0.58 & 20.61 & 2.24 & 0.19 & 0.27 & 1.80 & 7.16 & 7.44 & 0.06 & 0.11 & 0.12 & 0.35 & 96.95 & LST \\
\hline & 60.41 & 0.34 & 20.50 & 1.99 & 0.21 & 0.12 & 1.48 & 7.34 & 7.60 & 0.02 & 0.22 & 0.09 & 0.31 & 97.76 & LST \\
\hline & 60.40 & 0.57 & 20.36 & 2.20 & 0.17 & 0.24 & 1.90 & 6.80 & 7.32 & 0.03 & 0.10 & 0.08 & 0.28 & 97.72 & LST \\
\hline & 60.51 & 0.59 & 20.48 & 2.17 & 0.10 & 0.28 & 1.86 & 6.78 & 7.21 & 0.03 & 0.01 & 0.07 & 0.30 & 97.26 & LST \\
\hline & 59.62 & 0.42 & 20.79 & 2.27 & 0.23 & 0.20 & 1.60 & 7.50 & 7.35 & 0.02 & 0.17 & 0.05 & 0.35 & 96.99 & LST \\
\hline & 60.17 & 0.52 & 20.60 & 2.20 & 0.13 & 0.25 & 1.72 & 6.73 & 7.63 & 0.05 & 0.09 & 0.08 & 0.32 & 97.50 & LST \\
\hline & 59.73 & 0.53 & 20.34 & 2.43 & 0.11 & 0.31 & 1.77 & 7.01 & 7.70 & 0.08 & 0.15 & 0.09 & 0.29 & 97.32 & LST \\
\hline & 60.89 & 0.50 & 20.61 & 1.80 & 0.11 & 0.20 & 2.27 & 6.44 & 7.15 & 0.01 & 0.03 & 0.08 & 0.23 & 97.95 & LST \\
\hline & 62.51 & 0.41 & 20.03 & 1.45 & 0.08 & 0.18 & 2.39 & 4.96 & 7.93 & 0.05 & 0.06 & 0.08 & 0.11 & 97.34 & LST \\
\hline & 60.14 & 0.54 & 20.49 & 2.16 & 0.20 & 0.26 & 2.11 & 6.87 & 7.17 & 0.06 & 0.16 & 0.06 & 0.29 & 97.14 & LST \\
\hline & 59.52 & 0.52 & 20.43 & 2.38 & 0.20 & 0.29 & 1.77 & 7.24 & 7.60 & 0.06 & 0.26 & 0.10 & 0.30 & 97.01 & LST \\
\hline & 60.16 & 0.31 & 19.86 & 2.70 & 0.40 & 0.23 & 1.80 & 7.81 & 6.74 & 0.00 & 0.23 & 0.18 & 0.41 & 97.04 & LST \\
\hline & 59.41 & 0.56 & 20.61 & 2.37 & 0.18 & 0.29 & 1.70 & 7.23 & 7.59 & 0.08 & 0.06 & 0.07 & 0.31 & 97.99 & LST \\
\hline & 59.81 & 0.57 & 20.71 & 2.30 & 0.19 & 0.28 & 1.77 & 6.89 & 7.42 & 0.05 & 0.18 & 0.07 & 0.31 & 97.75 & LST \\
\hline & 59.72 & 0.53 & 20.71 & 2.23 & 0.16 & 0.23 & 1.76 & 7.01 & 7.63 & 0.02 & 0.22 & 0.13 & 0.32 & 97.40 & LST \\
\hline & 59.84 & 0.54 & 20.49 & 2.42 & 0.14 & 0.25 & 1.66 & 6.99 & 7.63 & 0.04 & 0.12 & 0.07 & 0.33 & 97.79 & LST \\
\hline & 60.21 & 0.56 & 20.17 & 2.36 & 0.20 & 0.28 & 1.71 & 7.09 & 7.36 & 0.04 & 0.18 & 0.11 & 0.33 & 98.88 & LST \\
\hline & 59.87 & 0.53 & 20.30 & 2.57 & 0.19 & 0.31 & 1.79 & 6.85 & 7.51 & 0.09 & 0.20 & 0.09 & 0.30 & 98.06 & LST \\
\hline & 59.52 & 0.59 & 20.39 & 2.36 & 0.22 & 0.28 & 1.78 & 7.17 & 7.61 & 0.07 & 0.20 & 0.13 & 0.29 & 97.23 & LST \\
\hline & 62.49 & 0.33 & 20.75 & 0.96 & 0.01 & 0.02 & 2.55 & 4.39 & 8.46 & 0.04 & 0.02 & 0.06 & 0.03 & 97.04 & LST \\
\hline & 60.42 & 0.55 & 20.19 & 2.31 & 0.19 & 0.29 & 1.72 & 6.87 & 7.41 & 0.04 & 0.15 & 0.09 & 0.32 & 98.90 & LST \\
\hline avg. & 60.22 & 0.51 & 20.47 & 2.20 & 0.17 & 0.24 & 1.88 & 6.82 & 7.45 & 0.04 & 0.13 & 0.09 & 0.29 & 97.51 & \\
\hline $\pm 1 \mathrm{~s}$ & 0.81 & 0.08 & 0.29 & 0.37 & 0.07 & 0.07 & 0.29 & 0.74 & 0.37 & 0.02 & 0.07 & 0.03 & 0.07 & 0.57 & \\
\hline
\end{tabular}

LST: Laacher See Tephra. 

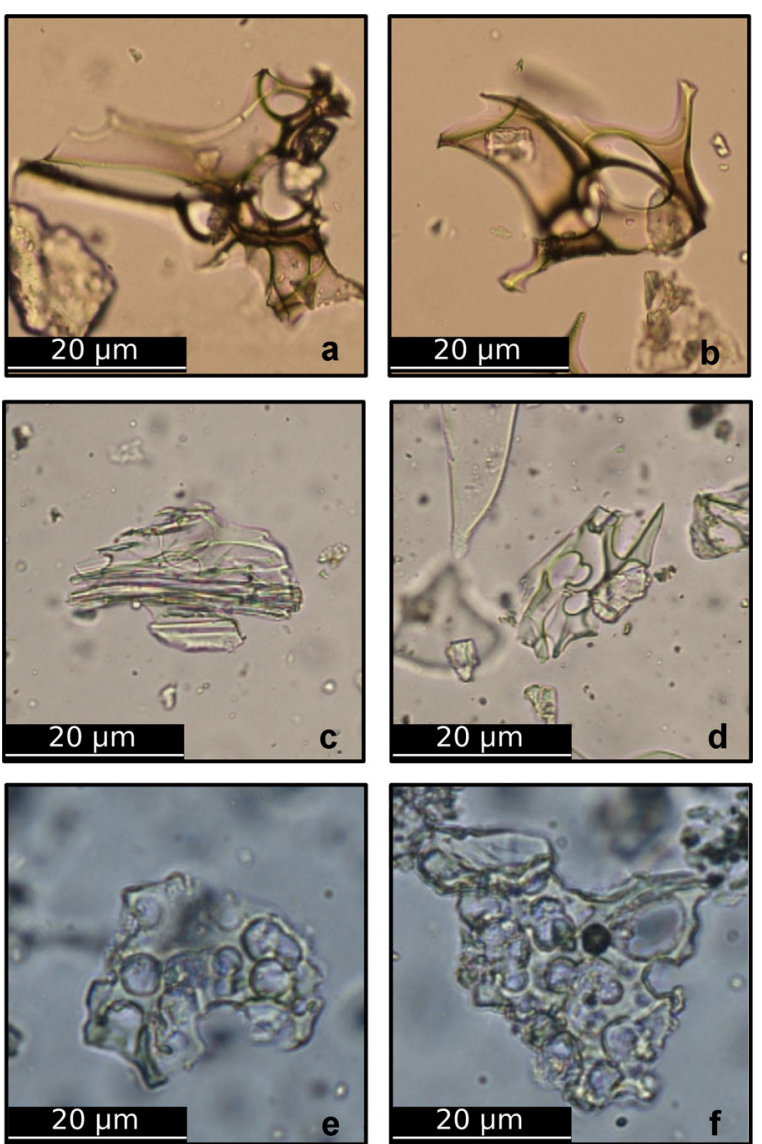

Figure 3. Images of cryptotephra shards from the Nahe palaeolake record; $a-b$ Saksunarvatn Ash, $c-d$ Vedde Ash, e-f Laacher See Tephra. [Color figure can be viewed at wileyonlinelibrary.com]

the main expansion of Corylus. Here, shard morphology has been utilised to distinguish between the two peaks. The lower peak contained brown platy and curvilinear shards, whereas the upper mainly comprised colourless shards with occasionally closed vesicles but mainly irregular morphologies. The lower and more distinct has been geochemically identified as a SA (Bramham-Law et al. 2013).

However, the double peak observed in the NAH record does not contain separate peaks of morphologically different shards. The geochemical composition of the lower and more pronounced peak clearly reflects a known SA fingerprint. Here, one explanation could be two temporally close successive eruptions of the same volcanic system or two separate basaltic volcanic systems.

There is more than one known eruption from the Grímsvötn volcanic system that is linked to SA (Bramham-Law et al. 2013; Davies et al. 2012; Jóhannesdóttir et al. 2006; Wastegård et al. 2018; Wulf et al. 2016). Recent studies by Harning et al. (2018) and Wastegård et al. (2018) as well as the review by Óladóttir et al. (2020) demonstrated that there were at least three, potentially even seven, eruptions from the Grímsvötn volcanic system.

One ash plume was distributed towards the north-west of the system and was recorded in the Greenland ice cores (Rasmussen et al. 2006). At least one other dispersal envelope was directed towards the south-east, and has been identified at a variety of sites in continental Europe (Bramham-Law et al. 2013; Jones et al. 2018; Lohne et al. 2013; Merkt et al. 1993; Wulf et al. 2016). The SA recorded in the NAH is most likely related to this south-east dispersal fan.

In this respect, only single cryptotephra horizons associated with the SA have been recorded in annually laminated sequences in northern Germany (Dörfler et al. 2012; Jones

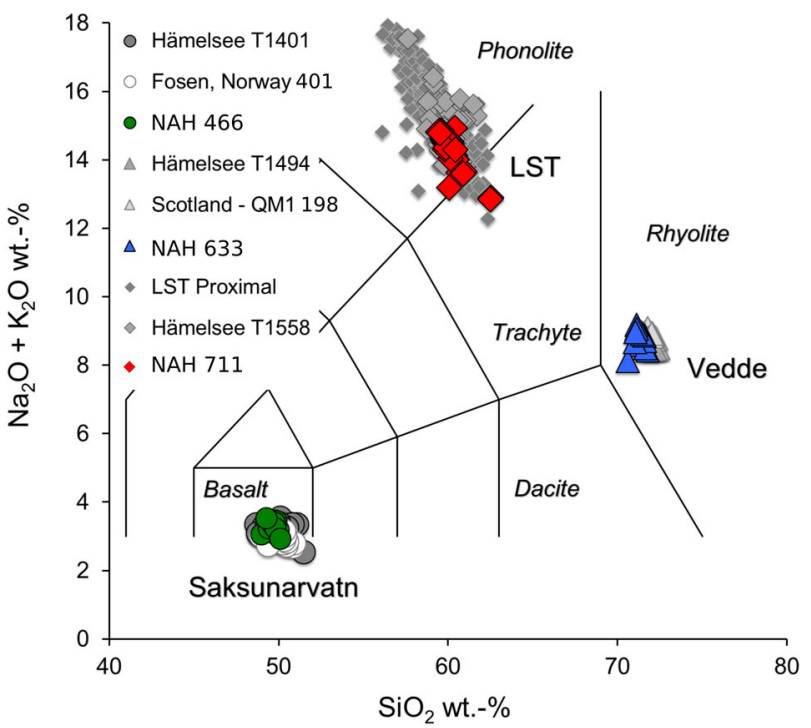

Figure 4. Classification diagram for volcanic glass shards from NAH466, NAH-633 and NAH-711. Total-alkali-silica classification diagram according to Le Bas et al. (1986). The geochemical composition of single glass shards of selected sites are given for comparison. For Saksunarvatn Ash the composition in nearby Hämelsee (Jones et al., 2018) and from Grønlia on the Fosen peninsula, Norway (Lind et al. 2013). For the rhyolitic part of the Vedde Ash the composition in Hämelsee (Jones et al. 2018) and Scotland (Timms et al. 2017) is displayed. Data on the Laacher See Tephra (LST) are taken from microprobe glass analyses from proximal LST Ash (van den Bogaard and Schmincke, 1985; unpublished data) and LST in Hämelsee (Jones et al., 2018). All data plotted are normalised to a volatile-free base. [Color figure can be viewed at wileyonlinelibrary.com]

et al. 2018; Merkt et al. 1993). One of those sequences derives even from Lake Poggensee (Zanon et al. 2019)-a lake less than $30 \mathrm{~km}$ east of the Nahe palaeolake.

(ii) The palaeo-environmental record of $\mathrm{NAH}$ revealed the presence of increasing amounts of undefined shells and shell fragments in the depth that corresponds to the SA. They can potentially be associated with small-scale lake-level fluctuations within the Nahe palaeolake. This assumption is in line with indicators of small-scale rearrangement. Therefore, it is probable that the two separate peaks can be explained by the redeposition of material or a secondary inwash of shards, respectively. Consequently, redeposition could be considered as a determining factor for the observed distribution pattern of cryptotephra in the sediment sequence (NAH-460 and $\mathrm{NAH}-466$ ).

The SA is intended to provide an additional time span to the age-depth model of the NAH sequence. Therefore, the depth needs to be clarified to which the tephra is to be assigned. In this respect, the $\mathrm{NAH}$ record could be correlated to the pollen sequence from close by Lake Poggensee (POG; M. Zanon pers. com.). Here, the SA is embedded as a single visible layer in annually laminated sediments.

The results of the palynological analysis revealed that the curves of Corylus pollen ratios of $\mathrm{NAH}$ and POG match closely (pers. com. M. Zanon). This is not surprising as the distance is less than $30 \mathrm{~km}$ and the size as well as the catchment of the two lakes would be approximately equal. Palynologically, the SA was detected in the sediments of Lake Poggensee, exactly where the lower SA peak was detected in the NAH record. Considering this, the event horizon is assigned to the depth of the lower shard peak (NAH-466).

\section{$\mathrm{NAH}-633$}

The pollen stratigraphic location of the VA is challenging. The fallout date of the VA has been placed in the 

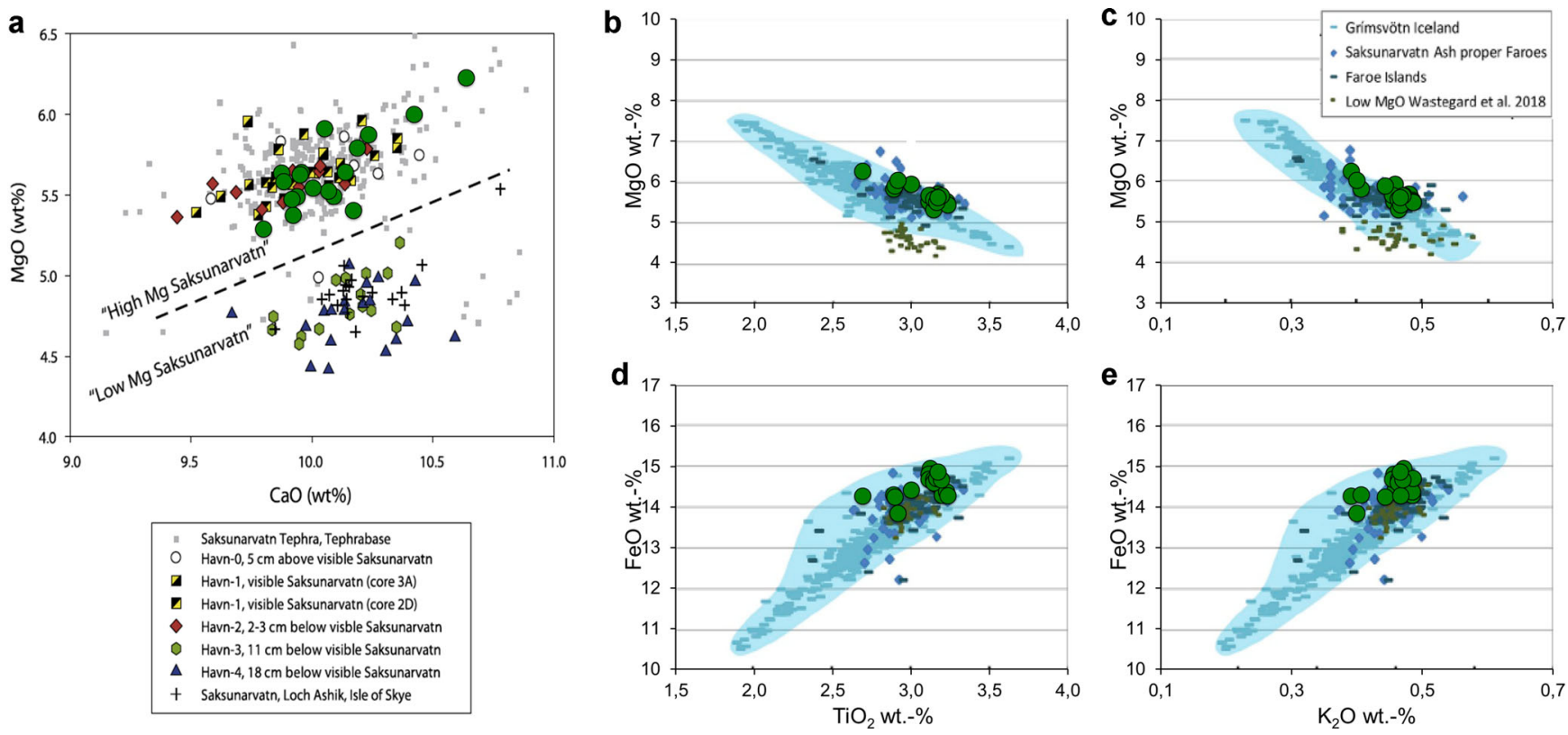

Figure 5. (a) NAH-466 glass shard composition (dark green dots) in the Saksunarvatn Ash discrimination diagram shown in Fig. 13 in Wastegård et al. 2018. Up to five ash horizons were described in one section on the Faroe Islands. (b)-(e) Selected bi-plots showing tephra glass shard majorelement compositions of G10ka series previously correlated to Saksunarvatn Ash proper at various selected sites around the North Atlantic adapted from Fig. 6 in Óladóttir et al. 2020. [Color figure can be viewed at wileyonlinelibrary.com]

mid-Younger Dryas period and was determined to represent a distinct marker horizon that separates the early and the later phase of the Younger Dryas period (Bakke et al. 2009; Haflidason et al. 2018; Lane et al. 2012a, 2013; Mangerud et al. 1984). The VA has been associated with pollen stratigraphy from Scotland (Lowe and Turney 1997), Sweden (Björck and Wastegård 1999) and Russia (Wastegård et al. 2000). For a pollen stratigraphic comparison with the present study, however, these are too remote to be used for comparison with the NAH record in northern Germany.

In north and north-western Germany, the second half of the (biostratigraphical) Dryas 3 period (terminology following Krüger et al. 2020) is linked to the spread of Empetrum sp. (cf. E. nigrum) in different degrees, reflecting climatic alterations towards increased oceanity (Krüger et al. 2020; Merkt and Müller 1999; Overbeck 1975). As an increase in Empetrum-type pollen has also been seen during the Dryas 3 period in the NAH record, a search for VA cryptotephra has been carried out in corresponding depths.

Here, the targeted search revealed one clear maximum concentration of shards in sample NAH-633 (14.245-14.265 m). The depth of the sample position corresponds pollen-stratigraphically directly to a rapid increase in Empetrum-type pollen values as observed midway through the Dryas 3 period (Fig. 2; Krüger et al., 2020).

Shard counts yielded about 395 shards/g. The shards are exclusively colourless (Fig. 3(c)-(d)). Morphologically, they appear platy to highly vesicular, and a few have tubular properties. The size spectrum ranges from 20 to $50 \mu \mathrm{m}$.

The tephra has a homogeneous geochemical composition. In the total-alkali-silica (TAS) classification diagram it falls into the field of rhyolite composition with $71.3 \pm 0.3 \mathrm{wt} \% \mathrm{SiO}_{2}$, $5.2 \pm 0.2 \mathrm{Na}_{2} \mathrm{O}$ and $3.6 \pm 0.1 \mathrm{~K}_{2} \mathrm{O}$ (Fig. 4). The full geochemical analyses are given in Table 2 .

The general characteristics of geochemical composition (Fig. 6), age and morphology of shards are in line with the description of shards of the rhyolitic phase found at sites across Northern Europe (among others: Davies et al. 2005; Mangerud et al. 1984; Timms et al. 2017, Jones et al. 2018).

\section{$\mathrm{NAH}-711$}

The Laacher See Eruption occurred after the palynologically defined termination of the Gerzensee Oscillation and around 200 years before the Dryas 3 period became fully established (Litt et al. 2003; Litt and Stebich 1999; Merkt and Müller 1999; von Grafenstein et al. 1994). In a number of pollen diagrams from north-eastern Germany a significant decrease of Pinus pollen values in the last third of the Allerød period is seen around the LST horizon (Jahns 2000; Theuerkauf 2003). This trend, albeit not strikingly pronounced, is observable in the pollen concentration values of the $\mathrm{NAH}$ record.

Here, the targeted search revealed one clear maximum concentration of glass shards at the 14.635-14.655 m core depth (NAH-711).

With respect to pollen stratigraphy, the sample depth corresponds to the last third of the Allerød period (Fig. 2). The high resolution of the pollen record allowed a clear distinction between the termination of the (palynologically defined) Gerzensee Oscillation and the timing of cryptotephra deposition (Dreibrodt et al. 2020; Krüger et al. 2020). It correlates to decreasing Pinus pollen values as well as increasing concentration values of pollen from grasses and herbaceous plants towards the end of the Allerød period.

Glass shard counts yielded about 160 shards/g. The tephra horizon consists of colourless vesicle-rich pumiceous shards with spherical vesicles, and pipe-like elongated bubbles (Fig. 3e-f). The external shape of these shards is determined by densely packed, open (burst) vesicle cavities. Single brownish shards occur. The size spectrum ranges from 20 to $75 \mu \mathrm{m}$.

Geochemical analysis was done on 31 shards (analyses that resulted in major-element weight percentage totals $<96 \mathrm{wt} \%$ were discarded). The tephra has a phonolitic composition with $60.2 \pm 0.8 w t \% \mathrm{SiO}_{2}$, a range of 7.8 to $4.3 \mathrm{wt} \% \mathrm{Na}_{2} \mathrm{O}$, a range of 8.4 to $6.6 \mathrm{wt} \% \mathrm{~K}_{2} \mathrm{O}$ and $2.6-1.5 \mathrm{wt} \% \mathrm{CaO}$. The full geochemical analyses are given in Table 3 .

The geochemical fingerprinting of the $\mathrm{NAH}-711$ glass shards confirms an identification with tephra from the Laacher See Eruption (Fig. 4). The glass shards of NAH-711 show the geochemical and morphological characteristics of the glass 

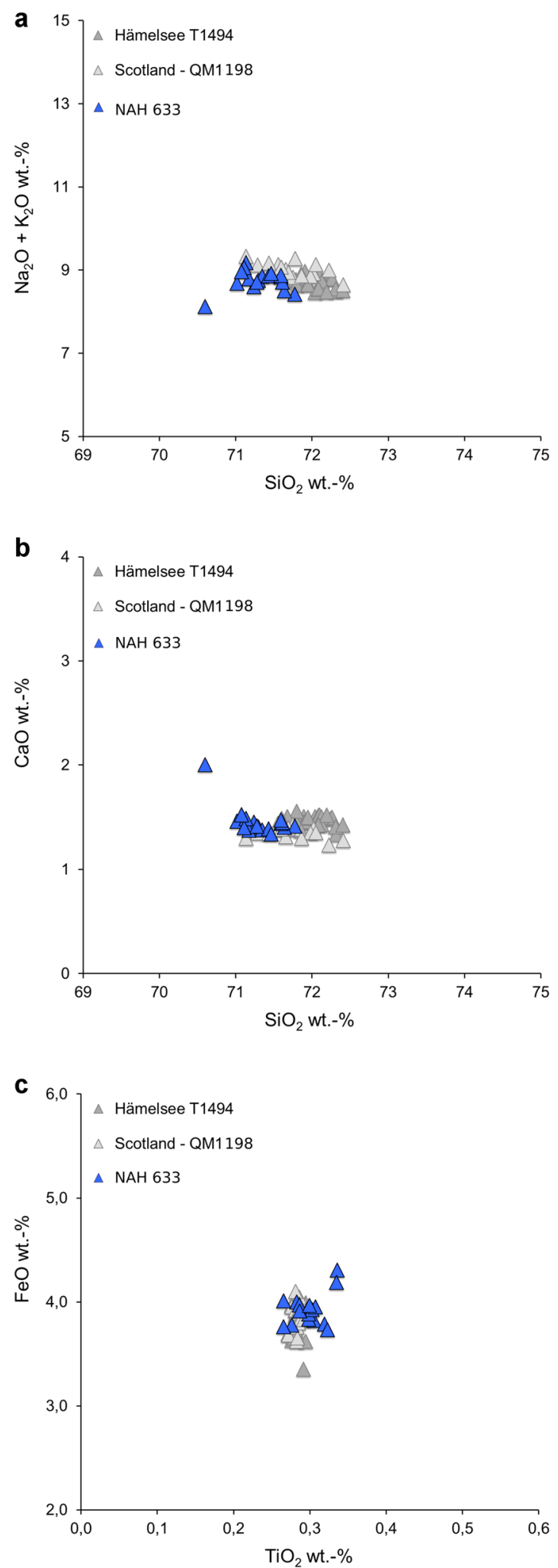

Figure 6. Geochemical composition of Tephra NAH-633 compared with the composition of the rhyolitic Vedde Ash at Hämelsee (Jones et al. 2018) and from Quoyloo Meadow, Orkney (Timms et al. 2017) in (a) $\mathrm{SiO}_{2}$ versus alkali, (b) $\mathrm{SiO}_{2}$ versus $\mathrm{CaO}$ and (c) $\mathrm{TiO}_{2}$ versus $\mathrm{FeO}$. [Color figure can be viewed at wileyonlinelibrary.com]

shards described from the proximal Plinian eruption phases (Fig. 3e-f), following the comparison with data from LST from the proximal type sites (van den Bogaard and Schmincke 1985; C. van den Bogaard, unpublished data).

The published data from distal sites in the north-western fallout (Housley et al. 2012; Jones et al. 2018; Lane et al. 2015;

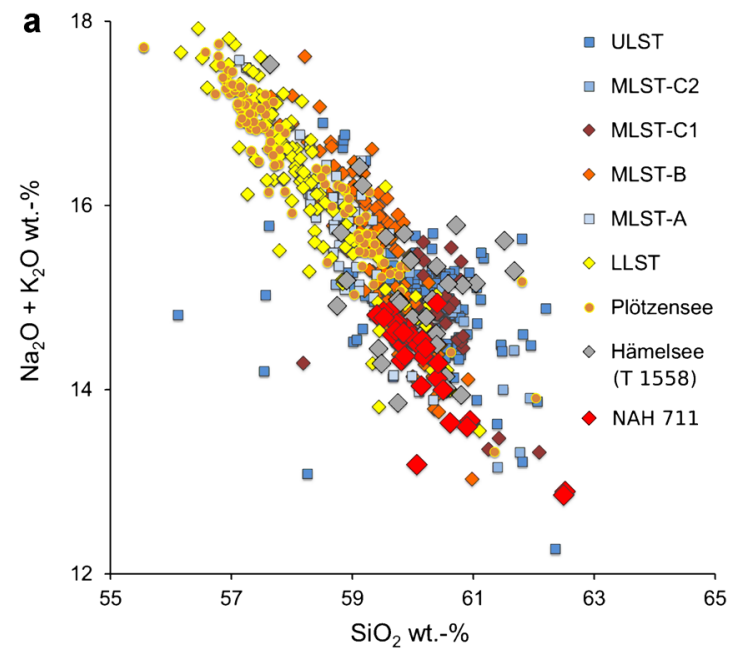

b
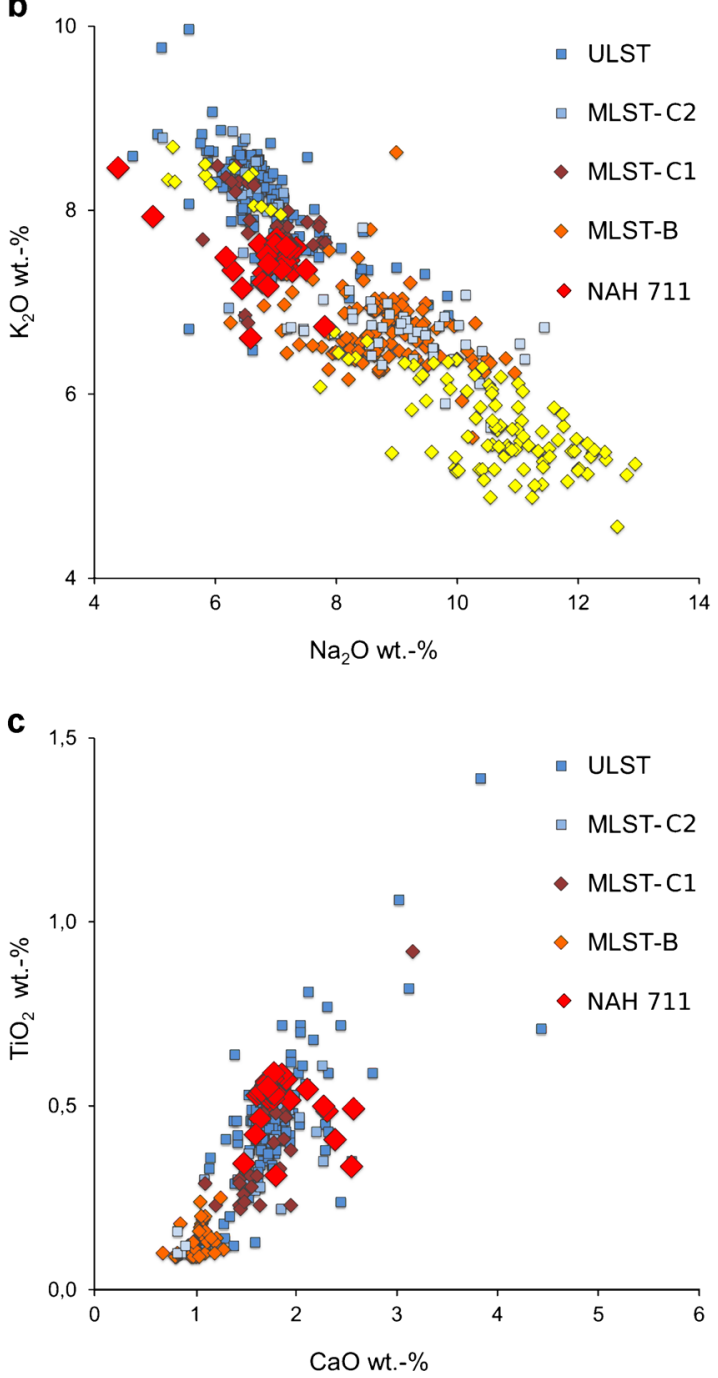

Figure 7. Tephra NAH-711 compared with glass shard composition of proximal Laacher See Tephra (LST) from the different eruption phases: LLST, MLST A, B, C1 , C2 and ULST (after van den Bogaard and Schmincke, 1984; unpublished data). (a) silica versus alkalis, glass shard composition from Plötzensee Berlin (unpublished data) represent the LLST fallout, (b) bi-plot $\mathrm{Na}_{2} \mathrm{O}$ versus $\mathrm{K}_{2} \mathrm{O}$ (c) and $\mathrm{CaO}$ versus $\mathrm{TiO}_{2}$. [Color figure can be viewed at wileyonlinelibrary.com]

Larsson and Wastegård 2018; Procházka et al. 2018; Riede et al. 2011; Turney et al. 2006; van den Bogaard and Schmincke 1984, 1985; Wulf et al. 2013) are in line with this interpretation. The chemistry suggests a fallout from the 
eruption phases MLST C1 (Fig. 7). This is also supported by the morphology of NAH-711 glass shards: the glass shards are highly vesicular and colourless. This is indicative of shards described from the LST eruptive phase that resulted from Plinian eruptions. Vesicle-rich pumiceous clasts with pipe-like elongated vesicles, are typical for LLST, MLST B and MLST C1 deposits, pumiceous clasts with spherical bubbles are described throughout the eruption sequence, but especially from LLST to the base of ULST. Glass shards from the phreatomagmatic phases of the eruption MLST A, MLST C2 and ULST are mostly angular and blocky with few vesicles (Jones et al. 2018; van den Bogaard and Schmincke 1985).

\section{Targeted cryptotephra search based on palynology}

It has been shown before that palynological records can be useful tools when intending to find cryptotephra layers (Dörfler et al. 2012). Preceding pollen analyses inherit the strength to narrow down the extent of the sediment sequence to be subsampled for tephra analysis.

In the present study, three cryptotephra layers out of three suspected were detected. The scope of the respective search sequence was in each case comparatively narrow $(7-16 \mathrm{~cm})$ due to the high resolution of the pollen record. Regarding all cryptotephra layers, the targeted search has been directly successful. Consequently, it must be questioned whether the detection of tephra in narrow sequences of very homogeneous sediments (here in the case of sediments deposited during the Dryas 3 and Boreal periods) means that cryptotephra is generally present throughout the sediment due to different depositional processes or turbations.

Nevertheless, with regard to the representation of shards per sample and depth of the VA and LST, large-scale rearrangement becomes very unlikely. In both cases a clear maximum of shards is recorded, considered to reflect the timing of the volcanic eruption and ash fallout. The presence of shards below the main peak can be explained by minor bioturbation (Anderson et al. 1984). As suggested by Davies et al. (2012), the concentration of shards per depth can decrease above the concentration peak, indicating the mobilisation of shards in the catchment. In this respect, the $\mathrm{NAH}$ cryptotephra record mainly contains expectable minor redepositions of shards resulting in a common tail-off pattern.

In order to exclude the possibility that shards are not generally present in every sample, specific sequences of transitional sediments were analysed. In addition, sequences were also considered in which no tephra layer would be expectable-this again on the basis of pollen stratigraphy and the current state of knowledge of tephra-producing events. Therefore, a sequence of $24 \mathrm{~cm}$ was selected spanning a transition from laminated to gradually more homogeneous sediments. According to pollen stratigraphy, this sequence was deposited during the last third of the Allerød period as well as during the transition from the Allerød to the Dryas 3 period. In the samples from the bottom of this sequence, the LST shows a clear peak. All samples above this maximum contained at most two shards, but predominantly no cryptotephra shards at all (cf. grey shaded areas shown in Fig. 2).

Consequently, two conclusions can be drawn. Firstly, only minor and expectable rearrangements of shards can be observed. This is in line with previous results from other approaches (Dreibrodt et al. 2020; Krüger et al. 2020). Therefore, large-scale rearrangements can be excluded.

Secondly, it becomes apparent that pollen stratigraphy is a very valuable instrument as a basis for a targeted search for cryptotephra horizons. However, this of course requires a high resolution of the palynological record as well as a profound knowledge of pollen stratigraphic positioning of the cryptotephra layers in compared regional diagrams.

\section{Tephrochronological discussion}

The detected cryptotephra layers could successfully be correlated by comparing their geochemical compositions with known volcanic eruptions of the Lateglacial and Early Holocene. NAH-466 correlates to a SA/G10ka series tephra, $\mathrm{NAH}-633$ to the VA and NAH-711 to the LST. Hence, we here present the first geochemically confirmed find of LST in Schleswig-Holstein-placed outside the known dispersal envelope of visible LST (Fig. 8) (Riede et al. 2011; van den Bogaard and Schmincke 1984).

These results provide three independent age estimates for the age-depth model of the NAH record. As only a segmental sequence of the sediment is laminated, we here refrain from estimating our own age model of the eruptions. Therefore, it is crucial to discuss which available chronological tie-points should be used for the individual events (Table 4).

For the LST, reference is made to Bronk Ramsey et al. (2015) who compiled and improved age estimates for Late Quaternary European tephra horizons. The age estimate for the LST is based on tree-ring data from Friedrich et al. (1999), as well age estimates from Holzmaar, Soppensee and Rotsee. The resulting $12937 \pm 23(\mu \pm \sigma ;$ IntCal13), is in good agreement with estimates by Brauer et al. (1999) and dating by van den Bogaard (1995).

The record from Lake Holzmaar (HZM; Zolitschka 1998; Zolitschka et al. 1995) provides lamination until recent times, inheriting the opportunity to easily correlate further sequences. One of these sequences is the Meerfelder Maar (MFM) sequence that is correlated to the HZM record by using the Ulmener Maar tephra as chronological anchor (Brauer et al. 1999). The MFM record in turn provided varves throughout the Younger Dryas and the mid-Allerød period resulting in a very accurate estimate of $12880 \pm 40$ varve years BP for the LST.

Based on 118 AMS ${ }^{14} \mathrm{C}$ dates from a sequence of Lake Kråkenes, Lohne et al. (2013 - IntCal09; 2014 - IntCal13) provided the most accurate dating of the VA to date. The age estimate of $12066 \pm 42 \mathrm{cal} \mathrm{BP}$ is in line with further estimates from lake sediments in Europe (Birks et al., 1996; Wastegård

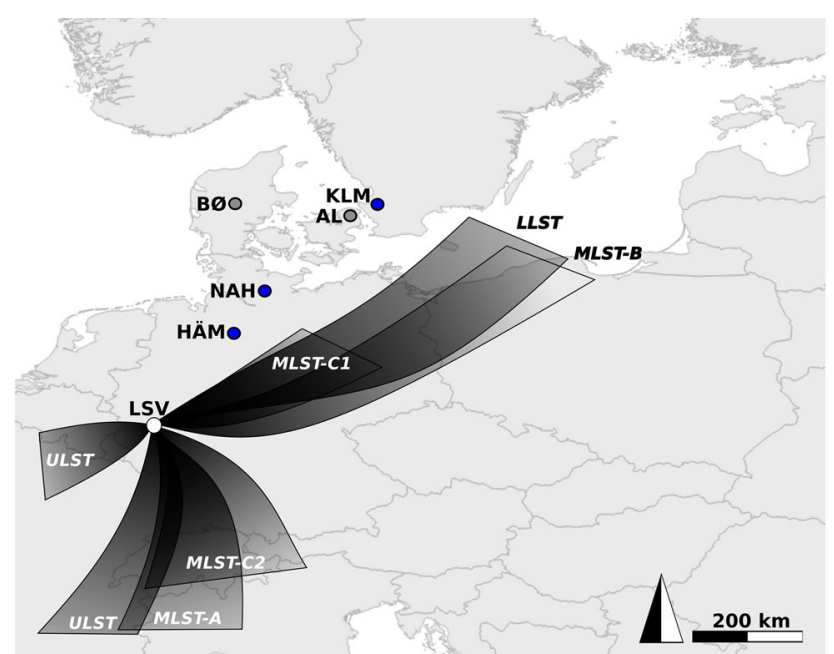

Figure 8. Estimated fallout of the Laacher See Tephra (LST) by van den Bogaard and Schmincke (1985) and modified by Housley et al. (2013), with the locations of the Nahe palaeolake (NAH), Körslättamossen (KLM; Larsson/Wastegård 2018), Lake Hämelsee (Ḧ̈M; Jones et al., 2018), the Allerød-type locality (AL; Hartz/ Milthers 1901) and the Bølling-type locality (BØ; Iversen 1942). [Color figure can be viewed at wileyonlinelibrary.com 
Table 4. Overview of recent dating of the respective cryptotephra horizons found in the Nahe palaeolake record.

\begin{tabular}{|c|c|c|c|}
\hline Sample & Correlation & Age estimate & Reference \\
\hline $\mathrm{NAH}-466$ & Saksunarvatn Ash & $10210 \pm 35$ cal. a вP & (Lohne et al. 2013) \\
\hline NAH-633 & Vedde Ash & $\begin{array}{ll}12 & 064 \pm 48 \text { cal. а вр } \\
12 & 023 \pm 43 \text { cal. а вр } \\
12 & 140 \pm 43 \text { varve а вр }\end{array}$ & $\begin{array}{l}\text { (Lohne et al. 2014) } \\
\text { (Bronk Ramsey et al. 2015) } \\
\text { (Lane et al. 2015) }\end{array}$ \\
\hline $\mathrm{NAH}-711$ & Laacher See Tephra & $\begin{array}{l}12937 \pm 23 \text { cal. а вр } \\
12880 \pm 40 \text { varve а вр }\end{array}$ & $\begin{array}{l}\text { (Bronk Ramsey et al. 2015) } \\
\text { (Brauer et al. 1999) }\end{array}$ \\
\hline
\end{tabular}

et al., 1998; Matthews et al., 2011) but provides a considerably smaller uncertainty.

The combined age model by Bronk Ramsey et al. (2015) to estimate the age of the VA is based on data from Lake Kråkenes, Abernethy, Soppensee, Rotsee and Bled. The resulting estimate of $12023 \pm 43(\mu \pm \sigma$; IntCal13) is in good agreement with the GICC05 date by Rasmussen et al. (2006).

In their analysis on the synchronicity of high-precision ${ }^{14} \mathrm{C}$ ages and the Greenland Ice Core Chronology, Lohne et al. (2013) further provided an age estimate for the SA of 10 $210 \pm 35(\mu \pm \sigma$; IntCal09). Based on the review by Óladóttir et al. (2020) it cannot be clarified with certainty to which of the G10ka series tephra the shards of the NAH record would correlate. Nevertheless, it has been shown that the pollen stratigraphical position of the lower shard peak from the NAH record correlates to the position of the SA layer in the pollen stratigraphy from Lake Poggensee (Zanon et al. 2019). At the near Lake Poggensee as well as Lake Woserin (Zanon et al. 2019; I. Feeser, pers. com.) only one ash layer has been identified in a laminated sequence. Both have been assigned to a SA (Zanon et al. 2019). As their individual dating falls well within the given age estimate by Lohne et al. (2013) this age has been utilised for the NAH age-depth model.

\section{Resulting tephrostratigraphical framework, regional implications and future work}

The identification of the volcanic eruptions allow for a direct correlation between the $\mathrm{NAH}$ sediment sequence and European key sites for palaeo-environmental research such as Meerfelder Maar (Brauer et al. 1999; Litt and Stebich 1999), Lake Hämelsee (Jones et al. 2018; Merkt and Müller 1999), Endinger Bruch (De Klerk 2002; Lane et al. 2012b), Lake Kråkenes (Lohne et al. 2013; Mangerud et al. 1984), Lake Tiefer See (Wulf et al. 2016) and Lake Soppensee (Lane et al. 2011; Lotter 2001). This highlights the relevance of the NAH location in correlating important key sites in northern and central Europe.

In combination with finds of LST at Lake Hämelsee (Jones et al. 2018) as well as Körslättamossen fen (Larsson and Wastegård 2018) the results of the present study demonstrate that the dispersal envelope of the Laacher See Eruption can be shifted further to the north-west.

In this respect it might even be possible to detect non-visible ash beds of the LST in Denmark (apart from Bornholm where it had already been identified-Turney et al. 2006) which would imply that biozonal-type localities such as Bølling (Krüger and Damrath 2019; Iversen 1942) or especially Allerød (Hartz and Milthers 1901) could finally be correlated to modern palaeoenvironmental investigations by event stratigraphy (Fig. 8).

The targeted search for cryptotephra comprised $18 \%$ of the total analysed NAH Lateglacial to Early Holocene sequence. Considering the extensive sections without a search for cryptotephra, it is evident that the sediment cores inherit the possibility of containing even more non-visible ash beds. The sequence already analysed palynologically covers spatially as well as temporally the eruptions and (predominantly) fallout zones of, e.g. Borrobol-type tephras, as well as Askja-S tephra, or Hässeldalen tephra (Davies et al. 2003; 2012; PyneO'Donnell et al. 2008; Turney et al. 1997; Wastegård et al. 2018; Wulf et al. 2016). Hence, we here emphasise the considerable potential of future investigations.

\section{Conclusion}

Three cryptotephra layers have been discovered and geochemically confirmed as G10ka series tephra (SA), VA and LST in sediments from the NAH. Consequently, we here present the first finding of LST in Schleswig-Holstein-located outside the ash plume that was reconstructed on the basis of visible ash layers. The combination of published LST findings from Lake Hämelsee (Jones et al. 2018) as well as Körslättamossen fen (Larsson and Wastegård 2018) reveals that the dispersal fan reached further to the north-west than previously assumed (Litt et al. 2003; Riede et al. 2011; Schmincke et al. 1999; Theuerkauf 2003; van den Bogaard and Schmincke 1985). Hence, the detection of LST in Jutland or the Danish Islands (adding to the finds on Bornholm) comes within reach, inheriting the potential to correlate important Lateglacial-type localities with recent palaeo-environmental investigations.

Furthermore, these results add three independent ages to the age-depth model for the NAH sequence (Dreibrodt et al. 2020), thereby emphasising the considerable potential for further investigations into both the site itself and general further tephrochronological studies in Northern Europe.

Acknowledgements. This article is part of a dissertation within the project B1 (Pioneers of the North, PI: B.V. Eriksen) of the CRC 1266, Scales of Transformation. We are thankful to Walter Dörfler, Ingo Feeser, Carola Floors, Svetlana Ibens and Marco Zanon as well as two anonymous reviewers for valuable suggestions. Funded by the Deutsche Forschungsgemeinschaft (DFG, German Research Foundation - Projektnummer 2901391021 - SFB 1266).

\section{Data availability statement}

All data generated or analysed during this study are included in this published article. Palynological data are available from the corresponding author on reasonable request.

\section{References}

Anderson RY, Nuhfer EB, Dean WE. 1984. Sinking of Volcanic Ash in Uncompacted Sediment in Williams Lake. Washington Science. 255: 505-508.

Andrews JT, Geirsdóttir A, Hardardóttir J et al. 2002. Distribution, sediment magnetism and geochemistry of the Saksunarvatn (10 180 \pm 60 cal. yr BP) tephra in marine, lake, and terrestrial sediments, northwest Iceland. Journal of Quaternary Science 17: 731-745.

Bakke J, Lie Ø, Heegaard E et al. 2009. Rapid oceanic and atmospheric changes during the Younger Dryas cold period. Nature Geoscience 2: 202. 
Bennike O, Sarmaja-Korjonen K, Seppänen A. 2004. Reinvestigation of the classic late-glacial Bølling Sø sequence, Denmark: chronology, macrofossils, Cladocera and chydorid ephippia. Journal of Quaternary Science 19: 465-478.

Beug H-J. 2004. Leitfaden der Pollenbestimmung für Mitteleuropa und angrenzende Gebiete. Verlag Dr. Friedrich Pfeil, München.

Birks HH, Gulliksen S, Haflidason H et al. 1996. New Radiocarbon Dates for the Vedde Ash and the Saksunarvatn Ash from Western Norway. Quaternary Research 45: 119-127.

Björck S, Ingólfsson Ó, Haflidason H et al. 1992. Lake Torfadalsvatn: a high resolution record of the North Atlantic ash zone I and the last glacial-interglacial environmental changes in Iceland. Boreas 21: 15-22.

Björck J, Wastegård S. 1999. Climate oscillations and tephrochronology in eastern middle Sweden during the last glacial-interglacial transition. Journal of Quaternary Science 14: 399-410.

Blockley SPE, Pyne-O'Donnell SDF, Lowe JJ et al. 2005. A new and less destructive laboratory procedure for the physical separation of distal glass tephra shards from sediments. Quaternary Science Reviews 24: 1952-1960.

Blockley SPE, Lane CS, Lotter AF et al. 2007. Evidence for the presence of the Vedde Ash in Central Europe. Quaternary Science Reviews 26: 3030-3036.

Bramham-Law CWF, Theuerkauf M, Lane CS et al. 2013. New findings regarding the Saksunarvatn Ash in Germany. Journal of Quaternary Science 28: 248-257.

Brauer A, Endres C, Günter C et al. 1999. High resolution sediment and vegetation responses to Younger Dryas climate change in varved lake sediments from Meerfelder Maar, Germany. Quaternary Science Reviews 18: 321-329.

Bronk Ramsey C, Albert PG, Blockley SPE et al. 2015. Improved age estimates for key Late Quaternary European tephra horizons in the RESET lattice. Quaternary Science Reviews 118: 18-23.

Davies SM, Wastegård S, Wohlfarth B. 2003. Extending the limits of Borrobol Tephra to Scandinavia and detection of two new Holocene tephras. Quaternary Research 59: 345-352.

Davies SM, Hoek WZ, Bohncke SJP et al. 2005. Detection of Lateglacial distal tephra layers in the Netherlands. Boreas 34: $125-135$

Davies SM, Abbott PM, Pearce NJG et al. 2012. Integrating the INTIMATE records using tephrochronology: rising to the chellenge. Quaternary Science Reviews 36: 11-27.

De Klerk P. 2002. Changing vegetation patterns in the Endinger Bruch area (Vorpommern, NE Germany) during the Weichselian Lateglacial and Early Holocene. Review of Palaeobotany and Palynology 119: 35.

Dörfler W, Feeser I, van den Bogaard C et al. 2012. A high-quality annually laminated sequence from Lake Belau, Northern Germany: Revised chronology and its implications for palynological and tephrochronological studies. The Holocene 22: 1413-1426.

Dreibrodt S, Krüger S, Weber J et al. 2020. Limnological response to the Laacher See eruption (LSE) in an annually laminated Allerød sediment sequence from the Nahe palaeolake (northern Germany). Boreas. https://doi.org/10.1111/bor.12468

Erdtman G. 1960. The acetolysis method. A revised description. Svensk Botanisk Tidskrift 39: 4.

Fægri K, Iversen J 1989. Textbook of Pollen analysis vol IV Edition. Leiden: John Wiley \& Sons.

Friedrich M, Kromer B, Spurk M et al. 1999. Paleo-environment and radiocarbon calibration as derived from Lateglacial/Early Holocene tree-ring chronologies. Quaternary International 61: 27-39.

Grönvold K, Óskarsson N, Johnsen SJ et al. 1995. Ash layers from Iceland in the Greenland GRIP ice core correlated with oceanic and land sediments. Earth and Planetary Science Letters 135: 149-155.

Haflidason H, Regnéll C, Pyne-O'Donnell SDF et al. 2018. Extending the known distribution of the Vedde Ash into Siberia: occurrence in lake sediments from Timan Ridge and the Ural Mountains, northern Russia. Boreas 48: 444-451.

Harning DJ, Thordarson T, Geirsdóttir A et al. 2018. Provenance, stratigraphy and chonology of Holocene tephra from Vestfirðir, Iceland. Quaternary Geochronology 46: 59-76.

Hartz N, Milthers V. 1901. Det senglaciale Ler i Allerød Teglværksgrav. Medd fra Dansk Geol Forening 8: 30.
Housley RA, Lane CS, Cullen VI et al. 2012. Icelandic volcanic ash from the Late-glacial open-air archaeological site of Ahrenshöft LA 58 D, North Germany. Journal of Archaeological Science 39: 708-716.

Housley RA, MacLeod A, Nalepka D et al. 2013. Tephrostratigraphy of a Lateglacial lake sediment sequence at Wegliny, southwest Poland. Quaternary Science Reviews 77: 4-18.

Iversen J. 1942. En pollenanalytisk Tidfæstelse af Ferskvandslagene ved Nørre Lyngby. Medd fra Dansk Geol Forening 10: 23.

Jahns S. 2000. Late-glacial and Holocene woodland dynamics and land-use history of the Lower Oder valley, north-eastern Germany, based on two, AMS 14C-dated, pollen profiles. Vegetation History and Archaeobotany 9: 111-123.

Jóhannesdóttir GE, Thordarson T, Geirsdóttir A et al. 2006. The widespread $\sim 10$ ka Saksunarvatn tephra: a product of three large basaltic phreatoplinian eruptions? AGU Fall Meeting Abstracts.

Jones G, Lane CS, Brauer A et al. 2018. The Lateglacial to early Holocene tephrochonological record from Lake Hämelsee, Germany: a key site within the Eropean tephra framework. Boreas 47: 28-40.

Krüger S, Damrath M. 2019. In search of the Bølling-Oscillation: a new high resolution pollen record from the locus classicus Lake Bølling, Denmark. Vegetation History and Archaeobotany 29: 189-211.

Krüger S, Mortensen MF, Dörfler W. 2020. Sequence completed palynologicalinvestigations on Lateglacial/Early Holocene environmental changes recorded in sequentially laminated lacustrine sediments of the Nahe palaeolake in Schleswig-Holstein, Germany. Review of Palaeobotany and Palynology 280. https://doi.org/10. 1016/j.revpalbo.2020.104271

Kuehn SC, Froese DG, Shane PAR, Participants II. 2011. The INTAV intercomparison of electron-beam microanalysis of glass by tephrochronology laboratories: Results and recommendations. Quaternary International 246: 19-47.

Lane CS, Blockley SPE, Bronk Ramsey C et al. 2011. Tephrochronology and absolutecentennial scale synchronisation of European and Greenland records for the last glacial to interglacial transition: A case study of Soppensee and NGRIP. Quaternary International 246: $145-156$

Lane CS, Blockley SPE, Mangerud J et al. 2012a. Was the $12.1 \mathrm{ka}$ Islandic Vedde Ash one of a kind? QuaternaryScience Reviews 33: 87-99.

Lane CS, De Klerk P, Cullen VI. 2012b. A tephrochonology for the Lateglacial palynological record of Endinger Bruch (Vorpommern, north-east Germany). Journal of Quaternary Science 27: 141-149.

Lane CS, Brauer A, Blockley SPE et al. 2013. Volcanic ash reveals time-transgressive abrupt climate change during the Younger Dryas. Geology 41: 1251-1254.

Lane CS, Brauer A, Martín-Puertas C et al. 2015. The Late Quaternary tephrostratigraphy of annually laminated sediments from Meerfelder Maar, Germany. Quaternary Science Reviews 122: 192-206.

Larsson SA, Wastegård S. 2018. The Laacher See Tephra discovered in southernmost Sweden. Journal of Quaternary Science 33/5: 477-481.

Le Bas M, Le Maitre R, Streckeisen A et al. 1986. A chemical classification of volcanic rocks based on total alkali-silica diagram. Journal of Petrology 27: 745-750.

Lind EM, Wastegård S, Larsen JJ. 2013. A Late Younger Dryas-Early Holocene tephrostratigraphy for Fosen, Central Norway. Journal of Quaternary Science 28/8: 803-811.

Litt T, Stebich M. 1999. Bio- and chronostratigraphy of the lateglacial in the Eifel region, Germany. Quaternary International 61: 12.

Litt T, Schmincke H-U, Kromer B. 2003. Environmental response to climatic and volcanic events in central Europe during the Weichselian Lateglacial. Quaternary Science Reviews 22: 7-22.

Lohne $\varnothing$, Mangerud J, Birks HH. 2013. Precise 14C ages of the Vedde and Saksunarvatn ashes and the Younger Dryas boundaries from western Norway and their comparison with the Greenland Ice Core (GICC05) chronology. Journal of Quaternary Science 28: 490-500.

Lohne Ø, Mangerud J, Birks HH. 2014. Correspondence. IntCal13 calibrated ages of the Vedde and Saksunarvatn ashes and the Younger Dryas boundaries from Kråkenes, western Norway. Journal of Quaternary Science 29: 506-507. 
Lotter AF. 2001. The palaeolimnology of Soppensee (Central Switzerland), as evidenced by diatom, pollen, and fossil-pigment analyses. Journal of Paleolimnology 25: 65-79.

Lowe DJ, Hunt JB. 2001. A summary of terminology used in tephrarelated studies. In Tephras: Chronology, Archaeology, Juvigné ET, Raynal J-P (eds). Les Dossiers de I'Archéo-Logis: CDERAD éditeur, Goudet; $17-22$

Lowe JJ, Turney CSM. 1997. Vedde Ash layer discovered in a small lake basin on the Scottish mainland. Journal of the Geological Society 154: 605-612.

Mangerud J, Lie SE, Furnes $\mathrm{H}$ et al. 1984. A Younger Dryas Ash Bed in Western Norway and Its Possible Correlations with Tephra in Cores from the Norwegian Sea and the North Atlantic. Quaternary Research 21: 85-104.

Matthews IP, Birks HH, Bourne AJ et al. 2011. New age estimates and climatostratigraphic correlations for the Borrobol and Penifiler Tephras: evidence from Abernethy Forest, Scotland. Journal of Quaternary Science 26: 247-252.

Merkt J, Müller H. 1999. Varve chronology and palynology of the Lateglacial in Northwest Germany from lacustrine sediments of Hämelsee in Lower Saxony. Quaternary International 6: 19.

Merkt J, Müller H, Knabe W et al. 1993. The early Holocene Saksunarvatn tephra found in lake sediments in NW Germany. Boreas 22: 93-100.

Mingram J, Negendank JFW, Brauer A et al. 2007. Long cores from small lakes-recovering up to $100 \mathrm{~m}$-long lake sediment sequences with a high-precision rod-operated piston corer (Usinger-corer). Journal of Paleolimnology 37: 12.

Moore PD, Webb JA, Collinson ME. 1991. An Illustrated Guide to Pollen Analysis. Blackwell Scientific: London.

Óladóttir BA, Thordarson T, Geirsdóttir A et al. 2020. TheSaksunarvatn Ash and the G10ka series tephra. Review and current state of knowledge. Quaternary Geochronology 56. https://doi.org/10.1016/ j.quageo.2019.101041

Overbeck FT 1975. Botanisch-geologische Moorkunde unter besonderer Berucksichtigung der Moore Nordwestdeutschlands als Quellen zur Vegetations-, Klima- und Siedlungsgeschichte Wachholtz, Neumünster.

Procházka V, Mizera J, Kletetschka G et al. 2018. Late Glacial sediments of Stará Jímka paleolake and the first finding of Laacher See Tephra in the Czech Republic International. Journal of Earth Sciences 108: 357-378.

Pyne-O'Donnell SDF, Blockley SPE, Turney CSM et al. 2008. Distal volcanic ash layers in the Lateglacial Interstadial (GI-1): problems of stratigraphic discrimination. Quaternary Science Reviews 27: 72-84.

Rasmussen SO, Andersen KK, Svensson AM et al. 2006. A new Greenland ice core chronology for the last glacial termination. Journal of Geophysical Research 111: 1-16.

Riede F. 2016. Changes in mid- and far-field human landscape use following the Laacher See eruption (c. 13,000 BP). Quaternary International 394: 37-50.

Riede F, Bazely O, Newton AJ et al. 2011. A Laacher See-eruption supplement to Tephrabase: Investigating distal tephra fallout dynamics. Quaternary International 246: 134-144.

Schmincke H-U, Park C, Harms E. 1999. Evolution and environmental impacts of the eruption of Laacher See Volcano (Germany) 12,900 a BP. Quaternary International 61: 61-72.

Smed P. 1998. Die Entstehung der dänischen und norddeutschen Rinnentäler (Tunneltälter) - Glaziologische Gesichtspunkte. Eiszeitalter und Gegenwart 48: 1-18.

Stockmarr J. 1971. Tablets with spores used in absolute pollen analysis. Pollen et Spores XIII 7.

Theuerkauf M. 2003. Die Vegetation NO-Deutschlands vor und nach dem Ausbruch des Laacher See-Vulkans (12880 cal BP). Greifswalder Geographische Arbeiten 29: 143-189.

Timms RGO, Matthews IP, Palmer AP et al. 2017. A high-resolution tephrostratigraphy from Quoyloo Meadow, Orkney, Scotland: Implications for the tephrostratigraphy of NW Europe during the
Last Glacial-Interglacial Transition. Quaternary Geochronology 40: $67-81$.

Turney CSM. 1998. Extraction of rhyolic component of Vedde microtephra from minerogenic lake sediments. Journal of Paleolimnology 19: 199-206.

Turney CSM, Harkness DD, Lowe JJ. 1997. The use of microtephra horizons to correlate Late-glacial lake sediment successions in Scotland. Journal of Quaternary Science 12: 525-531.

Turney CSM, Lowe JJ, Dawis SM et al. 2004. Tephrochronology of Last Termination Sequences in Europe: a protocol for improved analytical precision and robust corelation procedures (a joint SCOTAV-INTIMATE proposal). Journal of Quaternary Science 19: 111-120.

Turney CSM, den Burg KV, Wastegård S et al. 2006. North European last glacial-interglacial transition (LGIT; 15-9 ka) tephrochronology: extended limits and new events. Journal of Quaternary Science 21: 335-345.

Usinger H. 1981. Ein weit verbreiteter Hiatus in spätglazialen Seesedimenten: Mögliche Ursache für Fehlinterpretation von Pollendiagrammen und Hinweis auf klimatisch verursachte Seespiegelbewegungen. Eiszeitalter und Gegenwart 31: 17.

van den Bogaard P, Schmincke H-U. 1984. The Eruptive center of the Late Quaternary Laacher See Tephra (*). Geologische Rundschau 73: 933-980.

van den Bogaard P, Schmincke H-U. 1985. Laacher See Tephra: A widespread isochronous late Quaternary tephra layer in central and northern Europe. Geological Society of America 96: 1554-1571.

van den Bogaard P. 1995. 40Ar/39Ar ages of sanidine phenocrysts from Laacher See Tephra(12,900 yr BP): Chronostratigraphic and petrological significance. Earth and Planetary Science Letters 133: 163-174.

von Grafenstein U, Erlenkeuser H, Kleinmann A et al. 1994. High frequency climatic oscillations during the last deglaciation as revealed by oxygen-isotope records of benthic organisms (Ammersee, southern Germany). Journal of Paleolimnology 11: 349-357.

Wastegård S, Boygle J. 2012. Distal tephrochronology of NW Europe the view from Sweden. Jökull 62: 73-80.

Wastegård S, Björck S, Possnert G et al. 1998. Evidence for the occurrence of Vedde Ash in Sweden: radiocarbon and calendar age estimates. Journal of Quaternary Science 13: 271-274.

Wastegård S, Wohlfarth B, Subetto DA et al. 2000. Extending the known distribution of the Younger Dryas Vedde Ash into northwestern Russia. Journal of Quaternary Science 15: 581-586.

Wastegård S, Gudmundsdóttir ER, Lind EM et al. 2018. Towards a Holocene tephrochronology for the Faroe Islands, North Atlantic. Quaternary Science Reviews 195: 195-214.

Woldstedt P 1935. Erläuterungen zur Geologisch-morphologischen Übersichtskarte des norddeutschen Vereisungsgebietes im Maßstab 1:1500000. Preußisch Geologische Landesanstalt, Berlin.

Woldstedt P 1954. Das Eiszeitalter. Grundlinien einer Geologie des Quartärs. Erster Band. Die Allgemeinen Erscheinungen des Eiszeitalters. Ferdinand Enke Verlag, Stuttgart

Wulf S, Ott F, Slowinski M et al. 2013. Tracing Laacher See Tephra in the varved sediment record of Trzechowskie palaeolake in central Northern Poland. Quaternary Science Reviews 76: 129-139.

Wulf S, Dräger N, Ott F et al. 2016. Holocene tephrostratigraphy of varved sediment records from Lakes Tiefer See (NE Germany) and Czechowskie ( $\mathrm{N}$ Poland). Quaternary Science Reviews 132: 1-14.

Zanon M, Feeser I, Dreibrodt S et al. 2019. Sustained volcanic impact and ecosystem disturbance over continental Europe during the Early Holocene https://doi.org/10.31233/osf.io/ycrf3

Zolitschka B, Negendank JFW, Lottenmoser BG. 1995. Sedimentological proof and dating of the Early Holocene volcanic eruption of Ulmener Maar (Vulkaneifel, Germany). Geologische Rundschau 84: 213-219.

Zolitschka B. 1998. Paläoklimatische Bedeutung laminierter Sedimente: Holzmaar (Eifel, Deutschland), Lake C2 (NorthwestTerritorien, Kanada). Borntraeger: Berlin Stuttgart. 